Available online at: http://proceeding.rsfpress.com/index.php/pss/index

LPPM UPN “Veteran” Yogyakarta Conference Series

Proceeding on Political and Social Science (PSS)

Volume 1 Number 1 (2020): 192-199

\title{
Small Business Communication Strategy in Facing Crisis
}

\author{
Muhammad Edy Susilo, Prayudi \\ Universitas Pembangunan Nasional Veteran Yogyakarta \\ Email address edysusilo@upnyk.ac.id
}

\begin{abstract}
Crisis due to the Covid-19 pandemic has caused a worldwide crisis. Various sectors of life are affected by this crisis, including small businesses. This research reveals how the producer of Batik "Dewi Kunthi" Sleman, Yogyakarta, which is a micro-enterprise, survives the crisis. Researchers used qualitative methods by digging data in depth from critical sources, making observations, and looking for relevant literature. This research used Paul Argenti's concept in overcoming crises and Harold Lasswell's Model of Communication. The results showed that the group experienced frustration when hit by a crisis. None of the consumers bought their product, and the production process stopped for nearly two months. However, they seemed to have the toughness to face a crisis. They not only used the steps suggested by Argenti in dealing with the crisis but also went beyond it. Dewi Kunthi Batik Group diversifies its products and intensifies communication both internally and externally.
\end{abstract}

Keywords: crisis, micro-enterprise, product diversification, communication model Lasswell

\section{INTRODUCTION}

Small businesses are business actors that are proven to be able to survive in crisis conditions. Small businesses can save experience in the monetary crisis in 1998, Indonesia. In the period leading up to the resignation of President Soeharto, the economy experienced a crisis. The rupiah exchange rate dropped dramatically and affected the country's financial condition, which was primarily supported by imports.

In such conditions, the people's economy is excited because many goods and services usually come from imports have decreased in supply or have stopped due to being very expensive after appreciating the dollar (and the depreciation of the rupiah). Moreover, in the export commodity production sector, the people's economy even enjoyed a monetary crisis because their rupiah receipts increased "tremendously" (Mubyarto, 2001). At that time, many large investors and business people shifted their capital to other countries, so that the Indonesian economy was getting worse. However, small and medium enterprises were able to survive, tended to increase, and supported the wheels of the Indonesian economy. Small and Medium Enterprises (SME) is one of the industrial sectors that are only slightly affected by the global 
crisis that hit the world because SMEs can be taken into account in increasing market competitiveness. The role of SMEs at that time was seen as a lifesaver in the process of economic recovery. It encouraged economic growth and the workforce to prosper the people (Seran, Roron, Londa, 2017).

SME is a type of small-scale business and is not a subsidiary or branch of any company. It is a business that starts with a capital of around IDR 50,000,000. The number of employees is less than 20 people. Micro, Small, and Medium Enterprises (MSMEs) have a strategic role in the Indonesian economy. Data from the Ministry of Cooperatives and Small and Medium Enterprises of Indonesia in 2018 shows that the number of MSME business units is $99.9 \%$ of the total business units or 62.9 million units. SMEs to absorb $97 \%$ of total employment, $89 \%$ of which exist in the micro sector, and accounted for $60 \%$ of gross domestic product (Haryanti, Hidayah, 2018).

This article focuses on a small business is people's business, namely "Dewi Kunthi", located in Murang, Triharjo, Sleman District, Sleman Regency, is facing a crisis. A group was established in 2012 on the initiative of the Industry and Trade Service (Disperindag), Sleman Regency. This group of 20 members was formed to improve community welfare through empowerment in the economic field. Almost all members are housewives who initially did not have their income. The batik production that they are involved in is something entirely new for the members. Herein lies its attractiveness, namely from something new to a running business with quite a lot of production. On average, there are 1.200 pieces of batik cloth produced each year.

However, the dynamics of this business group were disrupted when the Covid-19 (Corona Virus Disease) pandemic hit in the first half of 2020. Production had to stop due to no orders. At the same time, members still had to survive in group activities. If there were group members discouraged by this condition, it could spread to other members and had a destructive impact on the group.

So quickly, this virus has spread to various parts of the world, causing an unprecedented crisis. All countries have closed access to the country. Many cities in the world are locked down or closed for access in and out. Air, land, and sea transportation stopped. Daily activities stop or transform into online activities.

Based on the website Coronavirus COVID-19 Global Cases in real-time, the numbers related to this case continue to increase. As of March 17, 188,638 cases of the Covid-19 virus were recorded in more than 90 countries globally. The highest number of cases is still in China, followed by Italy, Iran, Spain, and South Korea (Bahtiar, Saragih, 2020).

Moody's Investor Service predicts Indonesia's economic growth in 2020 will experience a slowdown at $4.8 \%$ of the Gross Domestic Product (GDP). This value is below the growth in 2019 , which was at $5.02 \%$. This economic slowdown predicted expected to continue in 2021 , even though it is accompanied by a slight strengthening, namely growing by only $4.9 \%$ (Thomas, 2020).

The economic sector is experiencing a significant impact. There were slumps everywhere. The European Union is experiencing the deepest recession, even the worst in 25 years. Regional GDP contracted or minus to $11.9 \%$ in the second quarter of 2020 . At the same time, 
the United States economy decreased by 32.9\% from April to June 2020. Meanwhile, the economy in Hong Kong contracted $-9 \%$ in the second quarter of 2020 (Arbar, 2020). In a crisis like this, the MSME sector needs special attention from the government because it is the most significant contributor to GDP and can be a mainstay in absorbing labor, substituting consumer goods or semi-finished goods.

The spread of this disease has become a crisis for business actors. A crisis is a situation, event, or prediction that threatens unexpectedly and unexpectedly, has a dramatic impact, damages reputation, and disrupts the sustainability of an individual or organization that drives the organization to the chaos that affects employees, products, services, and financial conditions. A crisis is a critical period related to an event that may harm the organization. Therefore, quick and precise decisions need to be made to avoid affecting the overall operations of the organization. This article answers the question of how are small business group communication strategies in dealing with crises?

\section{LITERATURE REVIEW}

Publicly Available Specification (PAS) defines a crisis as "an abnormal, unstable and complex situation, in which it is a threat to the strategic objectives, reputation or existence of an organization." In terms of the nature of the crisis, there is a sudden and smoldering crisis. The sudden crisis "was marked by an outright attack. They tend to be unpredictable and increase very quickly, often resulting from events or incidents that may occur outside of organizational control (Hamidovic, 2014).

Meanwhile, according to Sappriel, "an event, revelation, allegation or set of circumstances which threatens the integrity, reputation, or survival of an individual or organization. It challenges the public's sense of safety, values, or appropriateness. The actual or potential damage to the organization is considerable, and the organization cannot, on its own, put an immediate end to it (2003).

Crisis conditions are conditions that are not normal. Therefore, in this condition, extraordinary efforts are required. This is based on the idea that a crisis is like a crossroads. An ongoing crisis can lead to an organization's death, but there are also many success stories that a crisis can be a turning point towards a better condition than before the crisis.

Regional quarantine is carried out to reduce the rate of spread of the virus. By just staying at home, people are expected not to be exposed to this deadly disease. Coronavirus, among others, spread through air, droplets, and contaminated surfaces. If a person is forced to go outside, health protocol recommends that he wear a face mask. This item is something that everyone should have during a pandemic.

Businesses managed by small groups also experience the same condition. They must be slumped because of the pandemic that comes like a storm. The business groups that are founded by the community do not have reliable conditions to face this kind of situation. Let alone during a crisis, even in normal conditions, they are not too strong to stand up. However, organizations must not succumb to a crisis. In a critical condition, an organization must determine the mitigation of potential losses and handling risks, namely, reducing the 
possibility of disruption, shortening the period of disruption, limiting the impact of disruption to its main products and services (Hamidovic, 2014).

Some of the effects of the pandemic that caused a crisis for Dewi Kunthi's business group were the cessation of batik orders from consumers. In a crisis like this, people will prioritize more essential needs, such as consumer needs. People also spend money on items that are considered essential, such as medical equipment or materials. Vitamins, food supplements, hand sanitizers, and handwashing soap are considered more important than buying batik cloth.

Stopping orders resulted in the cessation of batik production. Group members no longer attend the workshop. Apart from having nothing to do, they also have to stay at home more often to follow the applicable health protocols. By being at home, health can be maintained, but what about reduced family income? How long will this take? Will the group disband? The questions above are the thoughts of all members and especially the group leader.

This article analyzes the results of research based on the concept of Paul Argenti in dealing with the crisis due to Covid and uses the communication component of Harold Lasswell. The steps to overcome the crisis from Argenti are as follows: Step 1: Create a Team for Centralized Communication; Step 2: Communicate with Employees; Step 3: Communicate Regularly with Customer; Step 4: Reassure Shareholders; Step 5: Be Proactive with Communities (Argenti, 2020).

To make this article to be more systematic and comprehensive, Harold Lasswell's concept regarding the elements of communication is also used, namely Who Says What In Which Channel To Whom with what Effect. This concept was discovered in 1940 and is perhaps the oldest concept not borrowed from other disciplines. This concept is also what makes Communication Science can be recognized as a separate discipline (Sapienza, Iyer, Venstra, 2015).

\section{RESEARCH METHODOLOGY}

This study used qualitative research methods, namely the research method used to examine natural object conditions, where the researcher is the key instrument, the data collection technique is done by triangulation (a combination of observation, interviews, documentation), data analysis is descriptive and qualitative research results emphasize meaning more than generalization (Sugiyono, 2017: 9). Primary data were obtained from interviews with the chairman and group members of Dewi Kunthi, in Sleman Regency, Yogyakarta Province. Researchers also made observations on group activities during the Covid-19 pandemic. Secondary data were collected from various relevant references.

The data analysis process was carried out from the beginning of the data collection process. Data analysis, according to Moleong (2014: 280), is the process of arranging the order of data, organizing it into a pattern, category, and basic description unit. In the analysis process, there are three main components, namely data reduction, data presentation, and concluding. Data reduction is the process of sorting, abstracting, and organizing research results. The presentation of data is compiling relevant data to make the information obtained is concluded 
and has meaning to answer research problems. Drawing conclusions is an attempt to seek or understand meaning, order, patterns, explanations, or propositions.

\section{FINDING AND DISCUSSION}

In crisis conditions, members tend to be inactive because they concentrate on more important things, namely personal and family health. Moreover, this is an official protocol from the government. The group leader saw this as a threat because the low intensity of the meeting could paralyze the group. The group leader can be seen as a communicator, namely the party who designs and delivers messages.

Group activities had been on hiatus for two months, namely May-June 2020. In the third month, he began to think that if there was too long a hiatus in activities, it could cause the group to disband. Group solidity is under threat. In fact, if seen from the group trip, they started this business from scratch, from a condition where they all do not know batik and business. Group spirit must be restored.

Internal group communication is intensified. The group leader gives the motivation to get the group members excited again. Of course, the group leader does not only provide verbal messages to members but also offers activities that the members can do. Members are encouraged to make any product without because, at that time, there are no orders from consumers.

If members are an internal part of the communicator, actually at the same time the group also has an external part. That section is the Department and Trade and of Industrybatik groups in Sleman regency who are members of the "Mukti Manunggal Community". So far, Disperindag is a companion as well as a source of orders for batik products. Most of the orders were in the form of a uniform batik with the "salak parijotho" motif, which is a typical Sleman batik.

In this pandemic situation, Disperindag took the initiative to make thousands of face masks with batik motifs. This item is a new product produced by the group. So far, they only produce batik, and some are sewn into ready-to-wear clothes. Making masks is not only challenging but can also raise the spirit of the group.

The chairman also has the initiative to diversify products by making laptop bags, travel bags, accessories, and sandals, all of which are made of batik. For the production of sandals, they work with sandal artisans. These items are made, even though no one has ordered them yet, to increase the group's activity. To produce batik like before the crisis, they were constrained by raw materials. The factory where they used to buy more cloth (white batik cloth), Primisima, in Sleman Regency, had stopped operating.

External communication with the community continues to be intensified. Disperindag Sleman founded the Mukti Manunggal community or association in 2016 with 27 groups as members. The purpose of establishing this association is to assist MSMEs with quality and character where they can increase the welfare of members by producing high-quality batik. In this condition, the association plays a significant role. They are all going through the same 
crisis and need to synergize with each other. As the name implies, in the association, they can work together and not compete.

The group needs to convey a message (says what) to the community that they still exist. The message consists of two aspects: the content of the message and the symbols used to express it. The content of the message tries to remind people that this group is still active even in crisis conditions. The content can be divided into two, namely verbally to audiences who can be met directly and through the media.

Talking about the media, this falls into "which channel" in Lasswell's term. The media chosen are mass media and social media. Networks in the mass media are obtained from lecturers who assist the group. During the pandemic, at least two pieces of news about this group were reported by reputable online media and conventional newspapers. This gives confidence for the whole group to move even though the conditions are still in crisis. Mass media does have a conferral status (Lemert, 2006). Everything that is covered by the media is considered to have higher importance.

This business group has long had social media accounts, namely Facebook and Instagram. However, they do not regularly update their status. Based on informants' information, they are not confident about posting something about their products on social media. They also feel stuttering information because they feel they are too old to post on social media. For information, all group members are over 35 years old. Another reason cited by the informants was that they did not have time to be active on social media. Their time has been divided between developing the group and taking care of their respective households.

The accompanying lecturer who carried out community service in this group tried to encourage the group to optimize social media as a medium of marketing communication. However, it is not easy to grow the confidence of group members who are not familiar with communication technology. On the other hand, they also need to be trained to take pictures, edit, and write interesting captions.

So far, they only use the Whatsapp (WA) chat application to market their products. Some group members have the habit of uploading statuses about products on the most popular chat application in Indonesia. Their target is all the people on their contact list, such as friends, neighbors, or relatives. Thus, each group becomes a sales force for the group.

In the audience and impact elements, they adjust to the media used, namely mass media and social media. That is, the coverage of the audience spans from the geographical side and various other characteristics. Understanding of the product also varies. Audiences who do not know can provide information, for audiences who already know will remind people of the product or even persuade them to buy the product.

Knowledge of marketing and skills in using social media is a prerequisite for getting the attention of the audience. The production process is stable so that organizations need to develop marketing aspects. Hopefully, when the pandemic ends "Dewi Kunthi" has already been one step ahead. 


\section{CONCLUSION AND FURTHER RESEARCH}

The author observes how Dewi Kunthi's business group tries to deal with the crisis using Lasswell's model. However, the results showed that the communicator element is an essential element. Managers have the tenacity to maintain team spirit and solidity. In a crisis, the production process comes to a halt. Member does not have any activity at work. When it drags on, the enthusiasm to work decreases. The group leader observed members who had given up hope and would not continue activities in the group.

In this crisis, the group leader tries to increase the morale of the members on the one hand and establish communication with the network of other batik producers in the Sleman district. Other batik producers also have the same problem, namely the lack of production and the uncertainty of the situation due to the pandemic. Thus, the group does not feel alone and can provide mutual support. As a result, group members experienced an increased enthusiasm for work.

After strengthening group solidity, they tried to intensify outgoing communication using mass media and social media. Media has the advantage of being able to reach large numbers of targets. Dewi Kunthi's batik group did not think much about the economic aspect because the conditions were not yet possible. The batik producing group "Dewi Kunthi" used the steps described by Argenti. They created an innovation, namely by diversifying the product. This is a local genius and needs to be researched in the future. However, this study has a limitation on the short duration of the study. In qualitative research, the longer the researcher is in the field, the better the quality of the research will be.

\section{REFERENCES}

Arbar, Thea Fathanah, 3 Maret 2020, Negara-negara Ini Resesi karena Corona, CNBC Indonesia, https://www.cnbcindonesia.com/news/20200803111313-4-177044/negaranegara-ini-resesi-karena-corona

Argenti, Paul, 13 Maret 2020, Communicating Through the Coronavirus Crisis, Harvard Business Review, https://hbr.org/2020/03/communicating-through-the-coronavirus-crisis

Bahtiar, Rais Agil, Juli Panglima Saragih, Dampak Covid-19 Terhadap Perlambatan Ekonomi Sektor Umkm, Kajian Singkat Terhadap Isu Aktual Dan Strategis, Bidang Ekonomi Dan Kebijakan Publik, Pusat Penelitian Badan Keahlian DPR RI, Vol. XII, No.6/II/Puslit/Maret/2020

Hamidovic, Haris, Volume 5, 2012, An Introduction to Crisis Management, ISACA JOURNAL, https://www.researchgate.net/publication/254864017

Haryanti, Dewi Meisari, Isniati Hidayah, 2018, Potret UMKM Indonesia: Si Kecil yang Berperan Besar, UKM INDONESIA, https://www.ukmindonesia.id/baca-artikel/62

Lemert, James, Status Conferral and Topic Scope, Journal of Communication, Volume 19, Issue 1, March 1969, published 2006, https://academic.oup.com/joc/articleabstract/19/1/4/4560868? redirectedFrom=fulltext

Moleong, Lexy, J. 2014. Metode Penelitian Kualitatif. Bandung : Remaja Rosdakarya 
Mubyarto, 2001, Mengatasi Krisis Moneter Melalui Penguatan Ekonomi Rakyat, Jurnal Ekonomi dan Bisnis Indonesia Vol. 16, No. 2, , 97 - 110

Sapienza, Zachary S., Iyer, Narayanan, Veenstra S. Aaron, 2015 Reading Lasswell's Model of Communication Backward: Three Scholarly Misconceptions, Mass Communication and Society, Routledge, 18:599-622,

Sapriel, Caroline, 2003Effective crisis management: Tools and best practice for the new Millennium, Journal of Communication Management, Henry Stewart Publications 1363254X Vol. 7, 4

Seran, Etni Debora S. Arie J. Rorong, Very Y. Londa, 2017, Pengaruh Pemberdayaan Usaha Kecil Dan Menengah Terhadap Kesejahteraan Masyarakat Di Kecamatan Tompaso Barat Kabupaten Minahasa, Jurnal Administrasi Publik, Volume 3 No 046, https://ejournal.unsrat.ac.id/index.php/JAP/article/view/16473/0

Sugiyono. 2017. Metode Penelitian Kuantitatif, Kualitatif dan R \& D. Alfabeta, Bandung Thomas, Vincent Fabian, Moody's Prediksi Ekonomi Indonesia Melambat di 4,8\% Akibat Corona, Tirto.id, 9 Maret 2020, https://tirto.id/moodys-prediksi-ekonomi-indonesiamelambat-di-48-akibat-corona-eDPW 